\title{
STRATIFIKASI SOSIAL DI TINJAU DARI ASPEK SANTRI DAN BUKAN SANTRI DI DESA WARGABINANGUN KABUPATEN CIREBON
}

\author{
Eddy Saputra \\ Program Studi Informatika, Universitas Indraprasta PGRI \\ Email: saputra2578@gmail.com
}

\begin{abstract}
Abstrak
Penelitian ini ditulis masih adanya stritifikasi sosial di kalangan masyarakat antara kaum santri dan bukan santri. Padahal ketika Islam di turunkan justru untuk menghapuskan stratifikasi yang pada waktu itu masih berlaku dikalangan bangsa arab. Pola stratifikasi seperti ini faktanya masih terjadi di masyarakat Indonesia, sekalipun orang-orang yang terlibat didalmnya memahami pengetahuan agama. Penelitian ini diharapkan mampu memberikan informasi bagi kita semua bahwa hakekatnya manusia dihadapan Allah swt sama. Penelitian ini menggukan metode kualitatif, dimana teknik pengumpulan data yang di gunakan melalui observasi secara langsung, wawancara kepada objek dan bukan objek yaitu kalangan santri dan bukan santri, informan melibatkan perangkat desa tokoh masyarakat serta sumber data lainnya. analisis terdiri dari tiga alur kegiatan yang terjadi secara bersama yaitu, reduksi data, penyajian data, dan verifikasi data kemudian di cocokan dengan kejadian dilapangan.
\end{abstract}

Kata kunci: stratifikasi sosial, santri dan bukan santri

\section{Abstract}

This research is conducted on a social stratification among the community, namely between santri (Islamic student) and non-santri. Even though such stratification has long been abolished since Islam existed among the Arabs in the past time, it in fact still exists in Indonesian society whose people practically understand religious knowledge. The research is expected to provide us information reminding us of the equivalence of human beings before God. The research uses a qualitative method, by which the data are collected from direct observation, interviews with santri, non-santri, and informants including village leaders and from other data sources. The data are analyzed in three simultaneous lines of activities consisting of data reduction, data presentation, data verification and are then matched to the occurrences in the field.

Keywords: social stratification, santri and non-santri:

\section{PENDAHULAN}

Masyarakat yang ada di indonesia sangatlah beragam, diantaranya terdapat perbedaan budaya, adat istiadat, suku, sampai dengan bahasa. Dari perbedaanperbedaan ini ada yang jauh spesifik didalam tataran masyarakat yang sama,yaitu trah atau yang lebih dikenal dengan stratifikasi sosial. Tataran masyarakat yang mengedepankan garis keturunan serta kedudukan didalam masyarakat. Di Indonesia sendiri bisa dikatakan hampir disetiap daerahnya masih mengedepankan pola stratifikasi sosial, baik secara terbuka ataupun tidak terbuka.
Stratifikasi sosial mengandaikan adanya lapisan-lapisan vertikal atau tingkatan secara status atau prestige, dan kekuasaan atau posisi sosial. Stratifikasi berposisi rendah, yang berkuasa dan yang lemah. Terdapat tiga dimensi dalam stsrtifikasi sosial yang bisa diamati dalam semua masyarakat, meliputi kekayaan, status atau kehormatan, dan kekuasaan namun masing-masing mempengarui sisi hidup kita, dimana kita tingggal, kemana kita bersekolah dan bekerja, apa yang kita makan, dan hobby apa yang kita gemari [1].

Banyak keterangan yang menyimpulkan strstifiaksi sosial yang terjadi di masyakat 
jawa pada umumnya terbagi menjadi tiga, yaitu kaum priyayi, santri dan abangan. Priyayi adalah kaum dari kalangan orangorang yang memiliki kedudukan di masyakarat seperti pemong desa, kecamatan atau sekup yang lebih besar, kaum santri adalah kalangan dari masyakarat yang taat dan patuh pada ajaran-ajaran agama, memilki kedudukan pada lembaga agama atau yang kehiduapannya berkutat di wilayah pesantren untuk belajar ilmu agama. Sementara kaum abangan, adalah orangorang bukan dari kalangan priyayai dan santri.

Geertz dalam relugion of java mendeskripsikan identitas muslim jawa dengan merumuskan trikotomi, abangan, santri dan priyayi, tardisi abangan yang dominan dari kalangan petani yang memiliki kepercayaan yang rumit terhadap roh-roh leluhur. Dilain pikak santri diasosiasikan sebagai islam yang murni. Ciri beragama kaum santri pelaksaan ajaran dan perintah-perintah dasar agama islam secara hati-hati dan teratur. Sementara kaum priyayi merupakan keturunan aristokrat(kaum ningrat) dan pegawai sipil komtemporer yang berperan penting dalam membentuk pandangan hidup dunia [2].

Desa Wargabinangun adalah sebuah desa yang terletak di sebelah barat kota Cirebon, sebuah desa kecil yang jauh dari hiruk pikuk aktifitas warga. Kehidupan warga desa tersebut di topang dari bertani. Banyak orang tua yang memiliki sebuah harapan besar pada generasi mereka untuk bisa menlanjutkan pendidikan agama ke pesantren. Santri adalah sebuah strstifikasi yang lebih realistis meraka capai, selain mendapatkan kehormatan, sebutan guru atau ustadz begitu melekat bagi orangorang yang berhasil menyelesaikan pendidikan agamanya di pesantren.
Menurut Nurcholish Madjid didasarkan atas kaum santri kelas literary bagi orang Jawa yang berusaha mendalami agama melalui kitab-kitab bertulisan dan berbahasa Arab. Kedua, pendapat yang mengatakan bahwa perkataan santri sesungguhnya berasal dari bahasa Jawa, dari kata "cantrik" berarti seseorang yang selalu mengikuti seorang guru kemana guru ini pergi menetap [3]. Kata santri sendiri di dalam kamus besar bahasa indonesia (KBBI), orang yang mendalami agama islam, orang yang beribadah sungguh-sungguh (orang saleh),serta yang mendalami pengajian dalam agama islam dengan berguru ke lembaga pendidikan seperti pesantren. Berbekal pelajaran yang di dapat dari pondok pesantren [4].

Santri sendiri dalam kehidupannya tidak bisa di pisahkan dari para guru-guru mereka yang sering di sebut Kyai atau ulama. Kyai atau ulama sering dijadikan tempat rujukan dan bertanya disaat ada permasalahan-permasalahan baik yang berkaitan dengan ilmu agama itu sendiri atau permasalahan yang terjadi di masyarakat.

Pola pembelajaran pada kaum santri hanya terpusat pada kita-kitab klasik yang juga di sebut kitab kuning, kitab bertulisakan huruf arab gundul yang di cetak pada lembaran-lembaran kertas yang berwarna kuning. Memerlukan metode khusus agar para santri bisa membaca kitab tersebut serta membutuhkan waktu yang panjang untuk dapat mempelajarinya.

Inilah salah satu kebanggan bagi kaum santri, keahlian membaca kitab kuning membuat para santri lebih percaya diri dalam menyampaikan ilmu agama karena diambil langsung dari sumbernya. Keilmuan serta pengetahuan dalam bidang agama membuat masyakat lebih menghargai dan menghormati. Tidak sedikit juga para santri alumnus pondok 
pesantren mendirikan lembaga yang sama di kampung halamannya atau sekedar atau sekedar menagajarkan ilmunya ke masyarakat.

Santri memeliki kewajiban menyampaikan pemgetahuannya di masyarakat dimana dai tinggal, ini menjadi tugas pokok bagi para santri ketika mereka pulang ke kampung halamanya masing-masing. Ketika para santri mulai mengajar pada saat itulah mereka memiliki kedudukan di masyarakat sedikit berbeda.

Santri dituntut berprilaku santun dan beradab, ini sebagai cerminan dari pengetahuan agama yang di miliki serta di aplikasikan dalam kehidupan sehari-hari, kalaupun ini juga bukan sebuah jaminan, jika orang itu santri maka memiliki prilaku yang baik, dan yang bukan santri maka prilakunya buruk. Akan tetapi santri dapat menjadi garansi dalam kelompok masyarakat untuk mendapatkan kedudukan atau kehorrnatan.

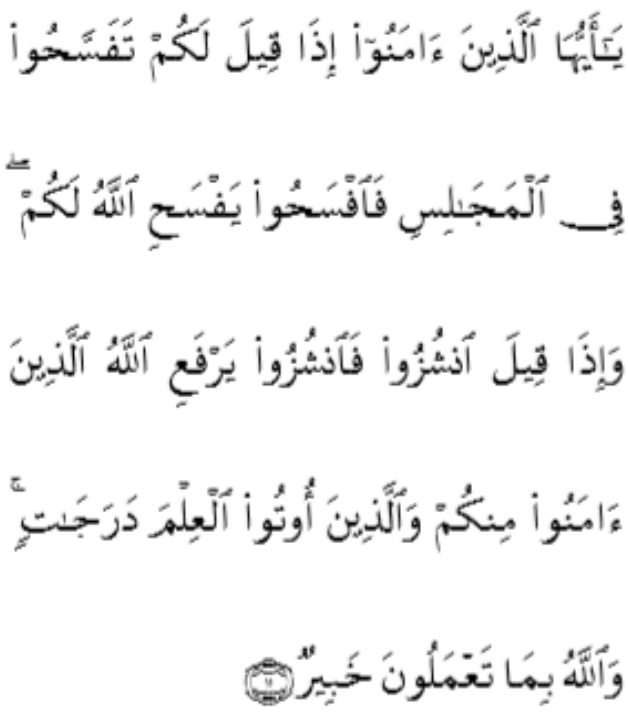

"Hai orang-orang beriman apabila kamu dikatakan kepadamu: "Berlapanglapanglah dalam majlis", Maka lapangkanlah niscaya Allah akan memberi kelapangan untukmu. dan apabila dikatakan: "Berdirilah kamu", Maka berdirilah, niscaya Allah akan meninggikan orang-orang yang beriman di antaramu dan orang-orang yang diberi ilmu pengetahuan beberapa derajat. dan Allah Maha mengetahui apa yang kamu kerjakan.

( Qs Al Mujadalah :11)

Ayat tesebut menerangkan, ketika kita dapat melapangkan waktu, tenaga maupun biaya dalam menuntut ilmu serta bersungguh-sungguh didalam mengikuti prosesnya maka ALLAH akan tinggikan derajatnya dari sebagian yang lain. Bisajadi itu adalah anugrah yang ALLAH SWT berikan bagi kaum santri yang sudah banyak menghabiskan waktu ,tenaga serta biaya untuk belajar sehingga mimiliki penegetahuan yang luas dalam bidang agama. Itu sebab kaum santri mendapat penghormatan lebih dari kaum yang bukan santri.

\section{METODE}

Pendekatan yang dilakukan adalah melalui pendekatan kualitatif. Artinya data yang dikumpulkan bukan berupa angka-angka, melainkan data tersebut berasal dari naskah wawancara, catatan lapangan, pengamatan, dan catatan resmi lainya, sehingga yang menjadi tujuan dari penelitian kualitatif ini adalah ingin menggambarkan realita empirik dibalik fenomena yang terjadi didalamanya secara rinci dan tuntas. Oleh karena itu penggunaan pendekatan kualitatif dalam penelitian ini adalah dengan mencocokan antara realita empirik dengan teori yang berlaku dengan menggunakan metodologi kulaitatif deskriftif [5].

Teknik pengumpulan data berdasarkan pengamatan langsung di lapangan yaitu desa wargabinangun kabupaten Cirebon terhadap objek yang akan di teliti, agar peneliti benar-benar mendapatkan data yang sesungguhnya, sehingga data dapat di jelaskan dan disajikan merujuk kepada kejadian yang benar-benar terjadi di lapangan. Pengamatan terhadap objek baik 
secara langsung maupun tidak langsung sehingga data dapat dihimpun berdasarkan fakta yang ada dilapangan, dan bukan merupakan rekayasa. Artinya data yang tersaji benar-benar terjadi di lapangan.

\section{Sumber data}

Data diambil dari secara acak (random) peneliti menentukan sendiri data yang diambil berdasarkan kebutuhan terhadap objek yang akan di teliti. Membagi dua klasifikasi masyrakat santri dan bukan santri

2. Teknik pengumpulan data

Dalam teknik mengumpulkan data menggunakan metode observasi secara langsung, wawancara kepada objek dan bukan objek, informan serta sumber data lainnya yang dapat melengkapi dari hasil penelitian.

3. Teknik dan analisis data

Analisis data adalah proses mengorganisasikan dan mengurutkan data ke dalam pola, kategori, dan satu uraian dasar sehingga dapat ditemukan tema dan dapat dirumuskan hipotesis kerja seperti yang disarankan oleh data. Analisis data merupakan proses mengolah, memisahkan, mengelompokan, dan memadukan sejumlah data yang akan dikumpulkan dilapangan secara empiris menjadi sebuah kumpulan informasi ilmiah yang terstruktur dan sistematis kemudian siap dikemas menjadi laporan hasil penelitian. Analisis data dalam penelitian ini menggunakan model Miles and Huberman yaitu interaktif model. Secara umum Miles dan Huberman beranggapan bahwa analisis terdiri dari tiga alur kegiatan yang terjadi secara bersama yaitu, reduksi data, penyajian data, dan verifikasi data [6].

\section{HASIL DAN PEMBAHSAN}

Stratifikasi yang terjadi di masyakat desa wargabinangun kabupaten cirebon terjadi secara alamiah merujuk pada keberadan di masyarakatnya. Pola ini berjalan dengan sendirinya tidak ada upaya yang dilakukan oleh kelompok-kelompok masyarakat untuk membentuk polarisasi tersebut. Tanpa di sadari dengan perjalanan hidup yang panjang serta kebiasaan yang dilakukan secara terun temurun pada akhirnya terbentuklah polarisasi yang di sebut stratafikasi sosial yang ada di desa wargabinangun kabupaten cirebon.

\section{Struktur sosial desa wargabinangun}

Desa yang terletak di sebelah barat kota cirebon adalah sebuah desa yang menggantunkan sumber pencarian sehari-harinya dari lahan pertanian. Lahan pertanian hanya di miliki dari kalangan masyarakat priyayi atau dari kalangan pejabat desa beserta keluarganya. Pejabat desa di berikan lahan pertanian yang di sebut tanah bengkok yaitu tanah yang di kelola oleh perangkat desa dimana hasil dari penegelolaan lahan tersebut sebagai bentuk lain dari honor atau gaji.

Lahan ini tidak boleh di perjualbelikan oleh perangkat desa, karena lahan ini pengelolaannya akan berganti apabila ada penggantian perangkat desa. Lahan yang disediakan tergantung teroterial luas desa dari masing-masing kecamatan yang ada di kabupaten cirebon. Untuk desa wargabingangun sendiri perangkat desa di berikan tanah bengkok seluas 12 hektar.

Sementara dari kalangan santri dalam menjalankan kehidupannya memilih mengabdikan serta menyalurkan ilmu pengetahuan yang di dapat melalui pondok-pondok pesantren. Dalam menyalurkan ilmu kaum santri banyak menduduki posisi, dari menjadi guru agama di masjid atau di langgar, 
menjadi pengasuh pondok atau bekerja di lembaga-lembaga agama, seperti pegawai kantor urasan agama atau menjadi pimpinan ormas islam tingkat desa dan kecamatan.

Dimasyarakat desa kaum santri mendapat penghormatan lebih tinggi dibandingan kalangan masyarakat lainya. Santri dalam hal ini kyai sering di jadikan tempat rujukan bertanya ketika penduduk desa ada masalah. Seringnya di libatkan dalam acara desa membuat kalangan santri makin dianggap lebih tingi dari pada kalangan yang lainnya. Masyarakat lebih percaya pendapat dari para kyai atau santri ketimbang dari perangkat desa.

Sementara disisi lain ada masyarakat yang bukan dari kalangan santri dan bukan kalangan priyayi. Masyarakat yang seperti ini jumlahnya lebih banyak dari pada kalangan santri dan priyayi. Ketidakmampuan mereka hanya menjadikan meraka sebagai buruh tani harian untuk menggarap lahan-lahan pertanian yang di miliki oleh kalangan priyayi dan santri.

Banyak dari kalangan mereka yang putus sekolah karena keterbatasan biaya, dan pada akhirnya hanya melanjutkan pekerjaan orang tua mereka sebagai buruh tani. Kalangan masyakat yang bukan santri terkadang sulit beradaptasi pada kalangan yang lebih tingi dari meraka, sekalipun berdasarkan pengamatan, kalangan santri dan kalangan priyayi tidak pernah membuat jarak pada mereka, akan tetapi masyarakat bukan santri seolah memehami kedudukan mereka, sehingga interaksi yang terjadi hanya sebatas keperluan masing-masing. Perasaaan-perasaan sanggung inilah tanda disadari membentuk sendiri polarisi yang ada di masrakat desa.
Dalam membangun perekonomian masyarakat bukan santri mencoba mendobrak kebiasaan yang terjadi sudah cukup lama. Merantau ke kotakota besar, terutama Jakarta. Sedikit dari kalangan mereka yang dapat berhasil dan mempu merubah kondisi menjadi lebih baik, mampu membeli tanah sebagai bekal untuk bertani dan memperbaiki rumah rumah-mereka agar lebih layak untuk di tempati.

\section{Startifikasi Santri dan Bukan Santri.}

Stratifikasi sosial antara santri dan bukan antri di desa wargabingangun masih terlihat, itu terlihat jelas dari observasi yang dilakukan dan itu di perkuat hasil wawancara dari beberapa informent yang bisa dianggap sahih serta di buktikan dari data perkawinan yang ada di kantor desa. Salah satu bentuk mempertahan sislsilah santri, diantara dengan menjodohkan anakanaknya dari kalangan santri juga.

Anak dari kyai haji Yusuf Khudori di nikahkan dengan anak dari kyai haji zamroni dari desa tetangga yan juga pengasuh pondok pesantren ujungsemi. Anak kyai haji Salim bagja di nikahkan dengan anak kyai haji khudori dari desa gua kidul sekalipun mereka bukan pengasuh pondok pesantren keduanya sangat kondang sebagai pendakwah, serta anak dari kyai haji Bhuseri yang dinikahkan dengan anak dari kyai haji Sukron dari desa Gedangan kabupaten Indramayu.

Sementara dari kalangan yang bukan santri dalam hal pernikahan lebih memilih dari kalangan mereka sendiri. Argumentasinya cukup beragam, sadar diri akan keterbatasan, mengukur diri dengan keadaan yang ada pada mereka, sampai pernah adanya penolakan dari masyarakat yang bukan santri ketika mau melamar anak dari kalangan santri. 
Yang jadi alasan paling banyak disampaiakan karena kekhawatiran terjadi penolakan. Sekalipun penolakan dari kalangan santri biasanya di lakukan dengan cara-cara menagajukan syarat ketika anak perempuannya mau dilamar dari kalangan yang bukan santri.

Sekalipun syarat yang di ajukan tidak terlalu sulit, tapi buat kalangan yang bukan santri syarat itu dianggap sebuah penolakan secara harus. Orang yang bukan santri diharuskan mengkhatamkan minimal satu kitab kuning yang bertulisakan arab gundul. Kalangan yang bukan santri faham betul untuk menghafalkan kitab yang hanya 30 halaman saja butuh waktu panjang, oleh karena itu syarat ini dianggap sebuah penolakan dari kaum santri.

Menurut keterangan kyai haji mukhyi seorang petugas kantor urasan agama sekaligus pemuka agama desa beliau menjelaskan, penolakan bukan berarti mengklasifkasi strata di masyarakat, kalangan santri hanya ingin mempertahankan penerapan ilmu agama pada generasi berikutnya, karena pendidikan anak di perlukan dua arah adanya pemahaman yang sama antara bapak dan ibu yang akan mengasuh buah hati mereka.

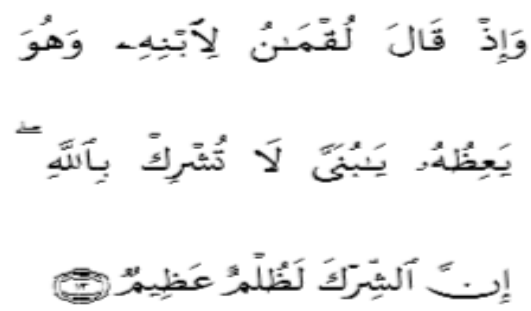

Dan (ingatlah) ketika Luqman berkata kepada anaknya, di waktu ia memberi pelajaran kepadanya: "Hai anakku, janganlah kamu mempersekutukan Allah, Sesungguhnya mempersekutukan (Allah) adalah benar-benar kezaliman yang besar".(QS Luqman 13)
Kyai mukhyi membacakan dan menjelaskan ayat tersebut. Dalam ayat tersebut ada pesan kepada orang tua untuk mengajarkan ilmu agama yang paling di prioritaskan bukan berarti ilmu umum di abaikan. Oleh karena itu bisa jadi alasan kaum santri mempertahankan garis pernikahan keluarganya. Sekalipun kyai mukhyi tidak menyangkal ada juga kyai yang membebaskan pilihan anak-anaknya untuk memilih pasanganya dalam pernikahan. Selama calon yang akan di nikahi anaknya masih dianggap baik akhlaknya. Akan tetapi kejadian ini jarang sekali terjadi.

\section{Urgensi Pendidikan Islam dalam Kalangan Santri}

Kalangan santri begitu identik dengan nilai-nilai keislaman oleh karena itu regenerasi dalam pendidikan harus terus di langsungkan, salah satu cara yang dilakukan adalah dengan mempertemukan kembali kalangan santri dengan kalangan santri yang lainya. Pendidikan agama merupakan pondasi yang utama, dari pengetahuan agama inilah kita dapat mengetahui mana yang baik dan yang buruk. Prilaku manusia yang baik bersumber pada nilai pendidikan Islam [7]. Pendidikan dalam Islam memiliki tujuan. Tujuan pendidikan Islam secara universal yaitu bahwa pendidikan harus di tujukan untuk menciptakan keseimbangan pertumbuhan kepribadian manusia secara menyeluruh Dengan demikian, pendidikan harus mengupayakan tumbuhnya potensi manusia, baik yang bersifat spiritua, intelektual, Tujuan akhir pendidikan terletak pada terlaksananya pengabdian yang penuh kepada Allah, baik pada tingkat perorangan,kelompok maupun kemanusiaan dalam arti yang seluas luasnya [8] 
Stratifikasi kalangan santri yang masih di pertahankan dalam rangka memberikan pengabdian pada masyarakat dalam aspek pendidikan Islam melalui lembaga-lembaga pendidikan yang mereka kembangkan.

\section{SIMPULAN}

Sekalipun tidak terlalu diagkat di permukan kondisi stratifikasi sosial antara santri dan bukan santri masih terasa begitu kuat. Kondisi tersebut masih di pertahankan sampai dengan sekarang, itu buktikan melaui pernikahan pada anakanak kaum santri yang memilih dari kalangan mereka, terkadang kaum santri berkomunikasi juga menggunakan bahasa arab, prilaku ini juga menguatkan dari kalangan kaum santri, sehingga kalangan yang bukan santri sadar betul akan posisinya.

\section{UCAPAN TERIMAKASIH}

Terimakasih kepada tokoh masyarakat, para kyai para perangkar desa, kepala desa, juru tulis desa serta kepada penduduk desa wargabinangun yang sudah membatu dalam pembuatan tulisan ini .

\section{DAFTAR PUSTAKA}

[1] Pranowo Bambang dkk, Sosiologi Agama. Jakarta: Laboratorium Sosiologi Agama, 2010.

[2] Memahami Islam Jawa. Jakarta: Pustaka Alvabet, 2009.

[3] Yasmadi, Modernisasi Pesantren: Kritik Nurcholish Madjid Terhadap Pendidikan Islam Tradisional (Jakarta: Ciputat Press, 2005)

[4] Pusat Bahasa Departemen Pendidikan Nasional Kamus Besar Bahasa Indonesia. Jakarta: Balai Pustaka. 2002.

[5] Moleong J lexy, Metode Penelitian Kualitatif, Edisi Revisi, Cetakan ke 1. Bandung: Remaja Rosdakarya, 2013.
[6] Sugiono, Metode Penelitian Kuantitatif dan Kualitatif R\&D. Bandung: Alfabeta, 2012.

[7] Winarno Herimanto, Ilmu Sosial dan Budaya Dasar, cetakan ke 4 Jakarta: Bumi Aksara. 2011.

[8] Jurnal Pendidikan Islam (E-ISSN: 2550-1038). 1(2). Hal. 215-234 Pengaruh Pemahaman PAI Terhadap Perilaku Sosial Siswa di SMK Unggulan NU Mojoagung Jombang. 2017 